\title{
Why Regimes Repress: The Factors that Lead to Censorship of Social Media
}

\author{
Ezhan Hasan \\ Department of Political Science, Texas Christian University, Fort Worth, TX \\ bttps:/ / doi.org/10.33697/ ajur.2019.028 \\ Student:azhan.hasan@tcu.edu \\ Mentors:j.scott@tcu.edu*,j.riddlesperger@tcu.edu,grant.ferguson@tcu.edu
}

\begin{abstract}
Social media have made it easier to create mass political action. Prominent examples include the Arab Spring movements, which took place in regions where information was previously tightly controlled by authoritarian regimes. Fearing radical change, several regimes have repressed social media use, but not all authoritarian regimes have taken the same measures. Previous research suggests that regime leadership is motivated to ensure its own survival but also influenced by a strong independent media and the need for citizens to vent grievances. To understand the relationship of these factors to social media repression, this research conducts a comparative process-tracing case study of Iran, Turkey, and Venezuela from 2004 to 2017, using a hypothesis-testing approach. It concludes with discussion of the findings for the nature of regime response to the role of social media in protest.
\end{abstract}

\section{KEYWORDS}

Internet; Media; Protest; Authoritarian; Iran; Turkey; Venezuela; Comparative; Case-Study

\section{INTRODUCTION}

In April 2018, the Sri Lankan government confronted mob violence targeting the Muslim minority in the nation. The primary response by the government was to completely shut down Facebook, claiming that it had amplified hate speech that incited the attacks. Officials ordered internet service providers in the region to stop allowing Sri Lankan users to send or receive any messages from the platform. ${ }^{1}$ The same tactic of shutting down social media had been used before this. About a year prior, the Jammu and Kashmir government blocked access to several social media sites, much like the Iranian government had done in 2008 , because the platforms were being used to advance anti-government propaganda. ${ }^{2}$ When countries do not want particular messages being seen, they ban particular users from social media or rely on the social media platform to censor for them. Similar to Turkish restriction of particular users' access in early 2014, Myanmar has blocked Arshin Wirathu, a Buddhist monk who preached intolerance of the refugee Rohingya population. ${ }^{3}$ Each of these countries has recognized social media's power to influence the information that people receive, along with the people's willingness to believe and act on the information. Social media, due to their ability to easily reach a vast number of people, have a special power to persuade that other forms of public discourse do not have.

Many cases of persuasion through social media involve the spread of untrue information. In Cambodia, several untrue claims about opposition party leader Kem Monovithya went viral on Facebook in 2017. Published dishonestly by those aligned with Prime Minister Hun Sen, the untrue allegations influenced public opinion to the point that opposition leaders were arrested and given sentences - all simply because of a few social media posts. ${ }^{4}$ Further, in the 2016 United States presidential election, Russian firms interested in stirring discord used social media to accomplish their goal. In the two years leading up to the election, these groups spread false information by garnering American followers and spreading digital ads. Through their spread of misinformation, they were able to organize rallies and events- from thousands of miles away via social media. ${ }^{5}$ The prospect of untrue messages on social media gives rise to a government's inclination to combat what it considers false, as in Iran, Turkey, Venezuela, and numerous other nations.

The use of social media has become a common factor in the spreading of information regardless of truth and regardless of government sanctioning of the information. In some cases, it leads to political action, both peaceful and violent. Several states have made decisions on banning social media platforms at least temporarily following one of these uprisings, but others have made no such decision despite the involvement of social media in harmful activities for the state. This research seeks to identify the factors that cause a state to censor social media, including the type of message, strength of the mainstream media, and wealth of citizens. It also seeks to identify the motivating causes behind particular cases of censorship in Iran, Turkey, and Venezuela. To 
understand the relationship of these factors to social media repression, previous research is used to generate three hypotheses, which are then tested using cases from Iran, Turkey, and Venezuela from 2004-2017.

\section{PROTEST AND SOCIAL MEDIA}

\section{The Power of Social Media}

The dispersion of information that sparks political change has quite obviously existed well before the advent of social media. Lohmann discusses one notable example of the power of information-a series of political protests in Eastern Germany beginning in 1989 and ending in 1991. In protests that occurred every consecutive Monday for thirteen weeks, "demonstrators expressed their demands for political liberalization, open borders, and, toward the end of the cycle, German unification." Lohmann attributes the speed with which the several protests grew to the concept of informational cascading - in simple terms, a process which involves a critically affected population passing information at high rates. In the case of political action, a more ideologically extreme portion of the population triggers the dispersion of negative assessment of the state, and as more moderate parts of the population slowly continue to spread the information, the government loses support from the public. Initially, members of society develop assessments of the nature of the state based on a private interaction with their government. Because each experience is different, these private assessments can either be positive or negative. It is likely that those with negative views will want political change, but "an individual receiver cannot unilaterally decide to overthrow the status quo regime; this is the collective decision of a large number of people." Through protest, those without the negative assessment are made aware of the views of those with the negative assessment and can then choose whether or not to adopt the views. Once the protests reach a certain threshold of support, they have enough power to overthrow the government. In the case of Eastern Germany at the time, there was no free press or other means of information dispersion. The onset of the demonstrations led to swift change because it spread information about negative experiences quicker than other media. ${ }^{6}$

It took a special set of circumstances to circumvent traditional mass communication channels in the Eastern Germany demonstrations. The advent of social media has made mass political mobilization much less difficult. The most prominent example is the Arab Spring — a series of protests that began in Tunisia and quickly spread to several nations in the Middle East. The wave of mass action was unprecedented for a region dominated by authoritarian regimes. The correct mix of factors was once again necessary for mass political action, and Bellin identified emotional triggers, impunity of state officials, and social media as the essential backdrop to the Arab Spring. Of these three, social media presence was the only factor that explained why these protests could not have occurred a decade prior to when they did. In several of these nations, the citizens' ability to do what Eastern Germans did two decades before them was hampered in the past by an "authoritarian bargain":

They exchanged political quiescence for stability as well as for economic growth. But even those citizens who rejected the authoritarian bargain found their capacity to organize politically blocked. The Tunisian and Egyptian regimes did everything in their power to suppress opposition and atomize society. Political activists were arrested and brutalized. Public gatherings were controlled, if not forbidden. Speech was censored and publications (especially in Tunisia) were often shut down.

Social media not only made up for the repressed communication channels but also proved to be more powerful than the alternate methods of uprising. Social media avoided authoritarian control through its "anonymity and spontaneity" and allowed for "coordinating and synchronizing thousands of people, making mass gatherings possible even in the absence of formal organizational infrastructure." This is the power of social media. Social media make it much more difficult for dictators to atomize society. Any regime that exercises control over other types of media would quite understandably be frightened by the prospect of immense power in the hands of the people granted by social media.

\section{Government Censorship Decisions}

Just as information dispersal had existed prior to social media, states had adopted techniques to control information that are now being applied to social media. Through a mathematical model, Edmond explains that if a regime's most important concern is survival, then its preferred state is to have a strong state-controlled centralized source of information. The state can then easily establish economies of scale to block or control all other sources of information. With more decentralized sources of information as is the case with social media, there is likely to be a larger number of information signals to each individual in the population, making establishing economies of scale much more difficult for the regime, which is unfavorable to its survival. ${ }^{8}$

If a state's interest is in controlling information, it is important for the state to acknowledge the scope of its power. Shadmehr and Bernhardt consider the regime's decisions under a model in which a strong independent media already exists, where it is not possible to completely control (as is the case with social media). They once again assert that censorship is beneficial to cementing power over the people, but that if it is overdone, it may be counterproductive. In these cases where no precedent exists for a completely state controlled media, rulers will censor existing media to the point that some negative stories may be released while still censoring the most negative stories. The rulers do this to maintain believability of the news: both the rulers and citizens realize that no government is perfect, and thus a media that only reports positive stories is not credible. Rulers recognize that 
complete censorship means that a single leaked negative story will have a huge impact on the regime's survival. ${ }^{9}$ Hassid's characterization of microblogs as safety valves and pressure cookers supports this idea. In China, social media criticism relieves social pressure when it simply comments on that which the mainstream media have already reported. This is referred to as the safety valve, which allows citizens to vent their frustrations without posing significant threat to the regime. It is also beneficial to a government that wishes to take feedback from citizens to improve and solve social problems. The other iteration of social media commentary is the pressure cooker, where citizens' commentary increases social tension. A pressure cooker occurs when bloggers express evaluations on issues the mainstream media are not discussing and therefore on which the government already has an established stance. The Chinese government has dealt with these more harshly because they are more likely to induce protest movements. ${ }^{10}$ Ultimately, decisions on censorship come down to governments controlling what they can but strategically allowing information dispersion when it least harms the regime.

Much of the existing understanding of social media censorship patterns comes from China, which has a complete ban on large social media outlets like Facebook and also has human enforcement that monitors the general internet. King, Pan, and Roberts conducted a study in which they automated several posts on various Chinese-controlled websites to examine patterns in what was censored and what was left on the web. Interestingly, Chinese officials did not censor everything that was oppositional to the government. In several cases, they allowed information with negative evaluations of Chinese leadership, with the exception of negative evaluations of the internet police. However, they consistently censored any information that encouraged collective political action. ${ }^{11}$ This is consistent with the idea that a regime's primary interest in censorship is cementing its own power, not necessarily having only positive public evaluation. The Chinese seemingly recognize what Aday and colleagues found: the unique power of new media, including social media, was organizing political action. ${ }^{12}$ Citizens would otherwise identify common interests and goals, but without social media, as in the cases preceding the Arab Spring, there would be no movement. Collective action has been more influential in controlling corruption than the presence of an electoral democracy. ${ }^{13}$ The Chinese government's motives for censorship give light to motives behind censorship in other nations.

Research into the Chinese model of censorship reveals the meticulous nature by which decisions are made on social media allowance. As Sullivan explains, the use of microblogging platforms in China can cause political change with the cooperation of the Chinese government. One of the primary platforms is Twitter, which is not technically allowed in China, but can still be accessed by some citizens using a Virtual Private Network (VPN). Although criticism of the government is generally not allowed in China, some Chinese social activists on Twitter or other microblogs are not stopped by the Chinese government, which actually uses some of the feedback to make changes in its governing. Chinese leaders allow this feedback loop primarily because they know the vast majority of citizens do not have access to Twitter, meaning that it cannot be used for inducing collective action. In this way, the microblogging platforms allow citizens to express their negative assessments of the government, but instead of primarily making others aware by triggering protest, the Chinese government uses the assessments to make positive changes. Essentially, Chinese officials overlook this loophole because the informational cascade doesn't reach the masses—it allows them to gain valuable feedback but does not threaten any sort of uprising. ${ }^{14}$

\section{THEORY AND HYPOTHESES}

The power of social media to encourage political action is of primary interest to this study. Political action that expresses negative assessment of an authoritarian government puts regime survival at risk. Repressive reactions (i.e. censorship) to that risk under different circumstances are the subject of this study. While recent research has been theoretical or focused on single countries as case studies, empirical cross-national research remains necessary to advancing knowledge on regime response to social media use. The regimes of interest to this study must be selective in determination of what to censor and not censor. In many strong democratic governments, there will be no repressive reaction by the regime to social media posts encouraging action because the government has strongly held values of press and speech freedom. For this reason, any nation with an average Polity score ${ }^{\mathrm{A}}$ of 8 or higher over the timeframe of this study has been excluded from the study and its implications. Some governments, such as the North Korean regime, repress all media indiscriminately, and are therefore also excluded from the study. For all other autocratic states, theoretical research suggests that avoiding mass political action is the primary reason that authoritarian regimes repress social media, and this study tests that idea cross-nationally. This study tests the Mass Political Action Hypothesis:

\section{Mass Political Action Hypothesis: When social media use encourages mass political action, authoritarian regimes respond with censorship.}

Existing research suggests refinements to this hypothesis based on other factors, which form the foundation for the remaining hypotheses. The example of Chinese Twitter use shows how when mass action is encouraged, but extremely unlikely to come into fruition, the regime will not repress the media. ${ }^{14}$ By extension, there may be cases in which mass action is encouraged by social media users but the general public either lacks access to the posts or is not receptive to the messages they see. In these cases, the

A Polity scores are a measure of the democratization of a nation, typically ranging from 0 to 10 . 
regime's primary concern is to prevent the pressure-cooker phenomenon, in which extreme negative sentiment builds up because citizens cannot express frustrations. ${ }^{10}$ The primary concern shifts only because mass political action is encouraged but unlikely to be realized. Regime survival is best achieved by allowing social media to serve as the safety valve by which citizens vent and relieve pressure. Therefore, this research tests the Unlikely Action Hypothesis:

Unlikely Action Hypothesis: When social media use encourages mass political action that is unlikely to be realized, regimes do not respond with censorship.

An important factor to consider is the amount of information that citizens can already access, prior to social media. In the case of a nation with existing strong independent mainstream media, a decision to censor social media messages will most likely backfire because the mainstream media will report on such censorship. Regimes will allow at least some negative stories to circulate in order to maintain the believability of the news. ${ }^{9}$ If there are no preexisting strong mainstream media, then it is easier for a regime to censor social media without consequences. Additionally, without strong independent mainstream media, the primary news source a citizen would have about events occurring in a different part of the country would be social media, outside of state media. In a nation that already controls the mainstream broadcast of events, maintaining control over national dialogue would require controlling social media. The Mainstream Media Hypothesis follows:

Mainstream Media Hypothesis: A regime in a nation with a strong independent mainstream media is less likely to repress social media than a regime in a nation with a weak mainstream media.

\section{RESEARCH DESIGN AND METHODS}

The cases of Iran, Turkey, and Venezuela are used from the period of 2004, the year when Facebook was launched, to 2017 to test the hypotheses. Consistent with Mill's method of agreement, this research uses different cases with the similar outcomes of having instances where social media are repressed and instances where it is not repressed. As such, two criteria were considered when choosing cases. First, the cases each have a known presence of protest movements and censorship. Second, the chosen cases are dissimilar in a number of relevant ways: level of democratization, ethnic fractionalization, ${ }^{\mathbf{B}}$ natural resource wealth, types of mainstream media, and GDP per capita. Each of these differences contribute to ensuring that similar censorship patterns are not simply indicative of overwhelming similarity between the cases. Table 1 summarizes the variation, with italicized values indicating lower levels, underlined values indicating median levels, and bold values indicating higher levels. Table 1 includes the average, as well as the minimum and maximum for the time period where available. A full table of the value for every available year is included in the appendix.

\begin{tabular}{|c|c|c|c|c|c|}
\hline Country & $\begin{array}{l}\text { AVG Polity } \\
\text { Score } \\
\text { (Minimum, } \\
\text { Maximum) }\end{array}$ & $\begin{array}{l}\text { Ethnic } \\
\text { Fractionalization }\end{array}$ & $\begin{array}{l}\text { AVG Natural } \\
\text { Resource Wealth } \\
\text { (Minimum, } \\
\text { Maximum) }\end{array}$ & $\begin{array}{l}\text { Mainstream Media } \\
\text { Description }\end{array}$ & $\begin{array}{l}\text { AVG GDP per } \\
\text { Capita } \\
\text { (Minimum, } \\
\text { Maximum) }\end{array}$ \\
\hline Iran & $-6(-7,-6)$ & 0.669 & $24.4(13.5,33.8)$ & Only state-run media & $5350(2729,7833)$ \\
\hline Turkey & $5(-4,9)$ & 0.229 & $0.442(0.28,0.71)$ & $\begin{array}{l}\text { Several privately } \\
\text { owned media sources }\end{array}$ & $\frac{10132(6040,}{\underline{12542)}}$ \\
\hline
\end{tabular}

Table 1. Summary of Variation on Independent Variables

The average polity score was calculated as the average from the Polity IV Project's data from 2004 to 2017 . Polity scores typically run from 0 to 10 , but in some cases (like Iran) there are negative values. ${ }^{15}$ Ethnic fractionalization scores were taken from Fearon and run from 0 to 1 , with higher scores indicating more fractionalization. ${ }^{16}$ Average natural resource wealth is a percentage of the nation's GDP taken as the average from 2004 to 2017 data from World Bank estimates. ${ }^{17}$ The description of mainstream media is based on descriptions from The World Factbook published by the CIA. ${ }^{18}$ Average GDP per capita is taken as the average of World Bank and OECD data from 2004 to $2017 .{ }^{19}$

For the analysis, CountryWatch reports are used to compile a list of all of the major political developments in each country. The list was not comprehensive but aimed to provide a representation of major events that would incite political discussion. These events were divided into Domestic Affairs, Elections, and International Relations. Domestic Affairs include changes in domestic

${ }^{B}$ Ethnic fractionalization is a measure of the number and prevalence of different ethnic groups in a country. 
policy, actions taken by the government within its own borders, and citizen-generated political action. Elections are specifically related to the occurrence of any election, a change in election rules, or a change in political parties. International Relations include any diplomatic or contentious dealings with other nations or international organizations (including terror organizations). Because the background research for this project does not discuss citizen response to international relations, those were excluded from the case study. From there, each domestic and election-related event is investigated to find evidence of social media discussion through the Nexus Uni database. In many cases, no evidence was found, either because it was unavailable (i.e. social media discussion did not happen or was not noteworthy enough to be included in reports) or evasive of key search terms. Those cases were excluded from further analysis. Also systematically discarded from analysis were terror attacks, which were prevalent in Iran and Turkey, because while these may be encouraged by social media, they do not fall under the same citizen-generated political discussion as the other cases. The exception to this, which is noted below, is in the case that discussion of terror attacks dominates discussions surrounding an otherwise domestic affair or election related event. While the remaining cases may not comprehensively cover every occurrence in each region, they still provide an accurate picture of different types of events that could lead to repressive response by the regime. The full list, as well as indications of which cases were excluded, is available in the appendix.

The goal of the analysis is to trace the process by which each regime makes a decision on whether or not to repress social media use. Relevant context surrounding each social media, protest, and/or censorship event is included for the purpose of highlighting factors that the regime may take under consideration in its response. Based on factors that consistently draw regimes in a particular direction, the hypotheses are evaluated.

\section{RESULTS}

Each case consists of a general background on the nation's varying natural resource wealth and GDP per capita. Following that are a summary of the proceedings of the events and discussion of the evidence of social media presence and/or censorship.

\section{IRAN}

The government of the Islamic Republic of Iran consists of a Parliament and a President, but also consists of an Ayatollah, or Supreme Leader, and a number of councils that serve as religious and constitutional checks on the government. Iran has a generally high level of ethnic fractionalization, measured at 0.669. Its average natural resource wealth is consistently high, and negotiations over oil production are ongoing international topics. Iranian citizens have extremely limited access to mainstream media, and the government also has attempted to restrict international broadcasts of the news. The range of GDP per capita is generally lower than the other two nations in this analysis. Iran begins as a very autocratic state and becomes slightly more autocratic over the course of this study. ${ }^{20}$

\section{Iran Social Media, Protest, and Censorship Events}

Table 2 provides a summary of the timeline, social media events, and government response for Iran. The full description of events follows below.

\begin{tabular}{|l|l|l|}
\hline $\begin{array}{l}\text { Approximate Time } \\
\text { Period }\end{array}$ & Description of Social Media Use & Government Response \\
\hline February-June 2004 & Calls for boycott of parliamentary elections & No censorship \\
\hline June 2005 & $\begin{array}{l}\text { Calls for boycott of presidential election; Online } \\
\text { election polling and discussion }\end{array}$ & No censorship \\
\hline March 2008 & $\begin{array}{l}\text { Promotion of government reform leading up to } \\
\text { parliamentary elections }\end{array}$ & $\begin{array}{l}\text { Selective censorship of particular } \\
\text { sites/messages and brief internet blackout }\end{array}$ \\
\hline 2009 & $\begin{array}{l}\text { Organization of mass protests and communication } \\
\text { with international organizations in the aftermath } \\
\text { of the presidential election }\end{array}$ & $\begin{array}{l}\text { Selective censorship of particular } \\
\text { sites } / \text { messages }\end{array}$ \\
\hline September 2010 & $\begin{array}{l}\text { General messages on a pro-government group } \\
\text { attacking Karroubi's home }\end{array}$ & $\begin{array}{l}\text { Continued selective censorship from 2009 } \\
\text { streets }\end{array}$ \\
\hline February 2011 & Organization of anti-government marches & Continued selective censorship from 2009 \\
\hline February 2011 & $\begin{array}{l}\text { General messages on the reportedly missing } \\
\text { Karroubi }\end{array}$ & Continued selective censorship from 2009 \\
\hline Mid-2011 & General messages on parliamentary elections & Continued selective censorship from 2009 \\
\hline February 2012 &
\end{tabular}




\begin{tabular}{|l|l|l|}
\hline 2012 & Videos of protests against high prices & No censorship \\
\hline May 2013 & General messages on presidential elections. & Continued selective censorship from 2009 \\
\hline February 2016 & $\begin{array}{l}\text { Protests of the disqualification of candidates in } \\
\text { parliamentary elections }\end{array}$ & Continued selective censorship from 2009 \\
\hline November 2017 & $\begin{array}{l}\text { Updates on earthquake and criticism of } \\
\text { government for wasting resources }\end{array}$ & No censorship \\
\hline
\end{tabular}

\section{Table 2. Summary of Iran Events over 2004-2017}

Over the period of February - June 2004, Iran was finalizing candidates for the parliamentary elections to be held in June. After the Council of Guardians disqualified thousands of reformist candidates from consideration, leading intellectuals and journalists called for a boycott of the election as a form of protest. Because they could not penetrate mainstream media, they used e-mails and mobile phone messages instead. While the government did not censor these messages, it did engage in its own campaign to encourage people to vote through the state-run news media. ${ }^{21}$

The June 2005 presidential election once again featured calls to boycott in response to the disqualification of several candidates. Around this time, internet interactions were becoming more common, as Iranian citizens had online contact with personal religious leaders. ${ }^{22}$ The internet was also used more heavily in the election to gauge public interest in candidates through polling, including a poll by the Iranian Students Polling Agency. In general, the government did not repress these opinion polls or the discussions on them, with the exception of polling done by individuals in contact with foreign officials. ${ }^{23}$

Preceding the March 2008 parliamentary elections, Parliament was reviewing proposals to cut the term of conservative President Mahmoud Ahmadinejad from four years to two-and-a-half years. At the time, Parliament was controlled by the conservative party, so the election of a majority opposition in Parliament was vital to the success of the proposed limits. Several pro-reform websites and chat services existed at the time of this election and were used in political conversation about the elections. Just before the election, the government restricted access to the Yahoo messenger service and Yahoo email sites, as well as SMS text messages found to be "destructive." ${ }^{4}$ On Election Day, the Iranian government reportedly shut down Internet access countrywide. ${ }^{25}$ After the election, Ahmadinejad's party maintained control of Parliament.

The primary candidates in the 2009 presidential election were former Prime Minister Mir Hossein Mousavi and incumbent Mahmoud Ahmadinejad. Election turnout in June 2009 was so high that polling stations had to extend operations for several hours due to long lines of voters. After polls closed, both Ahmadinejad and Mousavi claimed victory, with no official word on the matter. Soon after, Mousavi's website was shut off, his mobile messaging cut off, social networking curtailed, and headquarters reportedly raided. Iranian state media then declared Ahmadinejad the winner. What followed was the largest series of protests in Iran since 1979, which were called the "Green Revolution" by supporters of the reformists Mousavi and Mehdi Karroubi. Millions of protestors filled the streets, responding to calls by Mousavi and Karroubi to peacefully demonstrate. At that time, the hashtag “\#iranelection" was the most popular in the world and, along with pop star Michael Jackson's death, inspired Twitter's "trending" feature. Social media were used by Iranians to communicate to international news outlets, who were not allowed to report in the country. The government quickly took steps to curtail internet use and has held tight control over social media use since 2009. The mode of censorship from 2009 until the latest records have been very similar to Chinese censorship; several websites and social media websites have been blocked entirely but are still illegally accessible to Iranian citizens via Virtual Private Networks (VPNs). The Iranian government is selective in its censorship of the illegal social media posts from citizens but tends to exercise tightest censorship around elections. ${ }^{26-39}$ Based on this knowledge of general censorship patterns, messages surrounding major events in the ongoing social revolution are included as examples of continued selective censorship in Table 2 above.

In 2012, Iranian citizens had difficulty purchasing staples, such as rice and cooking oil, due to the harsh economic sanctions by the international community in response to disagreements over Iran's possession of nuclear capabilities. Scarcity resulted in a series of protests by citizens. Videos of protests were recorded and posted on social media, in which protestors are heard chanting "Death to High Prices." ${ }^{30}$ No evidence of censorship of these particular messages was found, but existing censorship laws remained in effect.

In November 2017, Iran experienced a 7.3 magnitude earthquake that killed hundreds of people and injured thousands more. Twitter users posted updates as the earthquake was happening and as they witnessed the devastation afterwards. ${ }^{31}$ Additionally, several users criticized the government for "wasting resources" in other countries, as a reference to Iran's ongoing aid in Syria. ${ }^{32}$ No evidence of censorship of these messages was found. 


\section{Summary of Findings from Iran}

Iran's government allowed unrestricted social media use for only a short time. The 2008 elections marked the first time the government experimented with social media censorship, and repressive measures were taken to full scale following the protests of the 2009 election. In accordance with the Mass Political Action Hypothesis, Iran censored social media use following mass political action, the largest example of which is the protests sparked by the 2009 election and anticipated mass action surrounding other elections. In these cases, the government likely wanted to avoid challenges to the regime that mass protest could have caused. Early lack of censorship may provide weak support for the Unlikely Action Hypothesis because political action was less likely to be realized before social media use became more widespread, but it may also be the case that the regime was also not yet well-versed in censorship methods. Because the internet is generally blocked but still accessible via VPN, social media posts that were not specifically blocked by the government after 2009, such as the 2012 difficulty in purchasing staples and the 2017 earthquake, also provide support for the Unlikely Action Hypothesis. As opposed to posts encouraging protests of the government's corruption, these messages generally contain weaker calls to action. The identifiable adversaries were the sanctioning nations in the 2012 case and an earthquake in the 2017 case. As a result, the government had less interest in censoring those messages. In accordance with the Mainstream Media Hypothesis, Iran was the only nation to feature a tightly statecontrolled mainstream media from the beginning of the time period of the study and began censoring social media relatively sooner than the other nations in the study. This suggests that the lack of available information via strong mainstream media enabled Iran to make information via social media also unavailable.

\section{TURKEY}

Turkey's government operates on a parliamentary representative system, where a Prime Minister heads the government and a president elected by Parliament heads the state. Turkey's ethnic fractionalization is measured at 0.229 , which is the lowest among the three cases in this study. Its natural resource wealth is consistently much lower than the other two cases at less than one percent of the country's GDP for the entire time period. Turkish citizens initially had access to "multiple privately owned national television stations and up to 300 private regional and local television stations, multi-channel cable TV subscriptions, [and] more than 1,000 private radio broadcast stations."18 Over the time period of this study, however, the government took measures to limit access to mainstream media. The GDP per capita in Turkey is very much comparable to the average GDP per capita for all nations in the world over the time period. Turkey begins as the most democratized nation in the study but becomes drastically more autocratic over the course of the study; it exhibits the widest range in Polity scores. ${ }^{33}$

Turkey Social Media, Protest, and Censorship Events

Table 3 provides a summary of the timeline, social media events, and government response for Turkey. The full description of events follows below.

\begin{tabular}{|l|l|l|}
\hline Approximate Time Period & Description of Social Media Use & Government Response \\
\hline August 2011- April 2012 & $\begin{array}{l}\text { Criticism of government for restricting } \\
\text { journalist access. }\end{array}$ & No censorship \\
\hline June-July 2013 & $\begin{array}{l}\text { Organization and coverage of mass } \\
\text { protests of Gezi Park repurposing. }\end{array}$ & Brief internet blackouts \\
\hline December 2013- March 2014 & $\begin{array}{l}\text { Spread of tapes of Erdogan alluding to } \\
\text { corrupt dealings in conversation. }\end{array}$ & Selective restriction of particular users \\
\hline March 2014 & $\begin{array}{l}\text { General messages on the release of } \\
\text { Basbug. }\end{array}$ & Continued selective restriction \\
\hline August 2014 & $\begin{array}{l}\text { General messages on presidential } \\
\text { election. }\end{array}$ & Continued selective restriction \\
\hline June- November 2015 & $\begin{array}{l}\text { General messages on parliamentary } \\
\text { election and subsequent snap election, } \\
\text { including messages on terror attacks and } \\
\text { journalist arrests. }\end{array}$ & $\begin{array}{l}\text { No censorship (although general } \\
\text { selective restriction continued) }\end{array}$ \\
\hline July 2016 & $\begin{array}{l}\text { General messages on attempted military } \\
\text { coup. }\end{array}$ & $\begin{array}{l}\text { Continued selective restriction, with less } \\
\text { enforcement }\end{array}$ \\
\hline April 2017 & $\begin{array}{l}\text { General messages on the referendum to } \\
\text { increase presidential power }\end{array}$ & Arrests of social media users \\
\hline
\end{tabular}

Table 3. Summary of Turkey Events over 2004-2007

From the period of August 2011 to April 2012, top military officials were arrested on charges of conspiring against the government. Early in 2012, the former head of Turkish armed forces General Ilker Basbug was arrested and other top officials were removed from their roles. Journalists were also arrested and were restricted access to covering military-related events. 
Leaders of news agencies criticized the government on social media for one of these events, the funeral of twelve Turkish soldiers who fought in Afghanistan, where reporters were denied entry to report on the event. ${ }^{34}$ Despite the attempted repression of mainstream news, there was no reported repression of social media.

In June and July 2013, protests surged in Gezi Park after the government announced its plans to repurpose the park. Initially, protests were peaceful in nature, but they soon became violent due to clashes with pro-government forces. Social media was key in organizing the protests, with over 20 trending hashtags including "\#occupygezi". Use of Twitter surged from 1.8 million uses per day at the end of May 2013 to 10 million uses per day in June. Photos depicting police violence circulated Facebook and Twitter to encourage more protest. Of those who participated in demonstrations, $69 \%$ received their news from social media, while only $7 \%$ received news from mainstream media, over which the government had tightened its grip. Prime Minister Recip Tayyip Erdogan made several anti-social media statements. For a short period of time during the protests, Internet access was cut off in Istanbul. ${ }^{35,} 36$

In December 2013, tapes of Prime Minister Erdogan talking to his son, alluding to corrupt dealings, were released. Protests, in which many labeled Erdogan a "thief" and called for him to resign, ensued in the beginning of 2014. Erdogan blamed social media, including Facebook, Twitter, and YouTube, for spreading false information on the subject. Erdogan took steps to regain control over the narrative in the nation, perhaps to keep the scandal from affecting his presidential campaign later that year. In March 2014, Erdogan pushed new legislation through parliament to increase his control over the internet and especially Twitter. Interestingly, while President Abdullah Gul and other members of the government maintained their Twitter accounts, all other Turkish users were banned. ${ }^{37}$

In March 2014, General Ilker Basbug was released from his life sentence in prison, as a court ruled that his rights were violated in the investigation process. This came as a blow to Erdogan, who had imprisoned Basbug for conspiring against him. At the time, bans on social media were still in place. ${ }^{33}$

In August 2014, Turkey held its first direct presidential elections and Prime Minister Erdogan of the AKP party was elected. On the campaign trail, internet restrictions were still in place from previous events, but many users were able to easily circumvent the obstacles. Erdogan's AKP party employed its own internet force to spread positive messages about the government on social media for the users that could still access it. ${ }^{37}$

Parliamentary elections were held in June 2015, and the AKP party won a plurality of seats but not a majority. Parliament found itself at an impasse in electing a prime minister until August, when it decided to hold another snap election in November. The second election in November 2015 resulted in AKP earning a majority of seats, and Ahmet Davutoglu was elected prime minister. Much of the national conversation surrounding the second election had to do with a series of attacks by the Kurdistan Worker's Party (PKK).C Turkish security concerns led to an increased trust in the government to handle the violence, which allowed the AKP to win the seats they needed. While Erdogan continued his campaign against media outlets in other respects, no social media censorship was found in connection to messages regarding these elections, possibly because most messages being spread were in favor of the ruling party gaining the majority they needed. ${ }^{33}$

In July 2016, after an attempted coup d'état, President Erdogan cracked down on several thousand soldiers and media outlets. Restrictions on social media from previous events continued, but with less enforcement. ${ }^{33}$

In April 2017, a referendum was held to increase the executive power of the president. The government repressed both mainstream media and social media opposition to the measures increasing Erdogan's power. Over 150 journalists were imprisoned, and over 170 media outlets were closed. While social media played a vital role in spreading the oppositional messages, more than 2500 individuals had been arrested for insulting the president on social media over the six months leading up to the referendum. ${ }^{38}$ The motion to increase executive power passed with 51.4 percent of the vote, and further protests ensued over what was considered a rigged election. ${ }^{39}$

Summary of Findings from Turkey

Turkey's history with social media censorship began in 2013, following the Gezi Park demonstrations, and continued intermittently over the course of the time period. In accordance with the Mass Political Action Hypothesis, Turkey censored social media following mass political action in the Gezi Park demonstrations and anticipated political action in Erdogan's 2014 scandal and the 2017 referendum. Interestingly, there was no specific social media censorship of discussion on the 2014 or 2015 elections, even though general restrictions are in place. Weak support is provided for the Unlikely Action Hypothesis. The only

C This reference of terror attacks is included because it dominates discussion of the November 2015 election. 
events with social media discussion that did not lead to mass political action concern the imprisonment of military leaders in 2011 and 2012 and the release of General Basbug in 2014. For the former, there was no evidence of social media censorship, and for the latter, general social media restrictions were still in place following the 2014 Erdogan scandal. The Mainstream Media Hypothesis is strongly supported, as crackdowns on mainstream media preceded social media censorship in every case. This suggests the government's steps to curtail information available via mainstream media opened the door to restriction of social media.

\section{VENEZUELA}

Venezuela's government initially operated as a federal presidential republic, although more power becomes concentrated in the hands of the executive over the course of this study. The president acts as both head of government and head of state. Legislative power is vested in a national assembly. The level of ethnic fractionalization is between that of the other two countries, measured at 0.483 . The natural resource wealth is high in this oil-rich nation throughout the time period of the study and is slightly under the resource wealth of Iran. Venezuelans have access to a mixture of state-run and private media in television and radio. While the government has always exercised heavy control on some stations, the control over private news sources varies throughout the time period of the study. The GDP per capita is about the same as the average of all other nations in the world over the time period and is very much comparable with the GDP per capita of Turkey. Venezuela experiences waves of severe and moderate levels of autocracy over the time period, with Polity scores that generally become lower over the course of the study.40

Venezuela Social Media, Protest, and Censorship Events

Table 4 provides a summary of the timeline, social media events, and government response for Venezuela. The full description of events follows below.

\begin{tabular}{|c|c|c|}
\hline Approximate Time Period & Description of Social Media Use & Government Response \\
\hline August-December 2006 & $\begin{array}{l}\text { Claims of government financial } \\
\text { mismanagement during presidential } \\
\text { election season }\end{array}$ & No censorship \\
\hline June 2011-March 2013 & $\begin{array}{l}\text { Messages in support of Chavez } \\
\text { throughout his battle with cancer, } \\
\text { including during presidential election } \\
\text { in October } 2012\end{array}$ & No censorship \\
\hline April 2013 & $\begin{array}{l}\text { General messages on snap } \\
\text { presidential election }\end{array}$ & Brief internet blackout \\
\hline 2014 & $\begin{array}{l}\text { Organization of mass protest and } \\
\text { heavy criticism of government; } \\
\text { general news about protest } \\
\text { movement }\end{array}$ & Selective censorship of messages \\
\hline February 2015 & $\begin{array}{l}\text { Messages about the death of teenager } \\
\text { Kluiver Roa Nunez }\end{array}$ & $\begin{array}{l}\text { Continued selective censorship from } \\
2014\end{array}$ \\
\hline December 2015 & $\begin{array}{l}\text { Messages in support of opposition } \\
\text { party in legislative election }\end{array}$ & Localized internet blackouts \\
\hline Late 2016 & Anti-Maduro messages & $\begin{array}{l}\text { Continued selective censorship from } \\
2014\end{array}$ \\
\hline July 2017 & $\begin{array}{l}\text { Opposition to Maduro's referendum } \\
\text { to increase his power by dissolving } \\
\text { parliament }\end{array}$ & $\begin{array}{l}\text { Continued selective censorship from } \\
2014\end{array}$ \\
\hline
\end{tabular}

Table 4. Summary of Venezuela Events over 2004-2017

In the 2006 presidential election, incumbent Hugo Chavez accused his opponents of spreading false rumors of a failing financial system via the Internet and cell phones. While Chavez rebuked the claims, there was no censorship of the messages. ${ }^{40}$

Concerns about President Hugo Chavez's health arose in June 2011 when the leader was reportedly taken to a hospital in Cuba to be treated. This came one year before the 2012 election season. Chavez addressed the Venezuelan people on several occasions, assuring them that he was recovering well and highly optimistic about his condition. Throughout the election, Chavez actively used his Twitter account to "garnish support as well as criticize his opponent." 41 As Chavez was taken back to the hospital after the election, his supporters both rallied in the streets and "lit up social media" to show their appreciation for the leader.42 Throughout the period from June 2011 to Chavez’s death in March 2013, Chavez had high approval ratings amongst the population. No evidence of social media censorship was found. 
After the death of Chavez in March 2013, a snap election was organized for April 2013, in which Chavez's successor would be decided. Throughout the election process, interim president Nicolas Maduro was in power. Social media was heavily used as a means of political conversation about the candidates, as there were over six million references of the election by over 800 thousand different users on social media. ${ }^{43}$ With Maduro and his opponent in a close race, internet access was completely blocked for a brief period of time just before the election. ${ }^{44}$ Maduro narrowly claimed victory, leading to small-scale oppositional protests.

In 2014, protests ensued over economic mismanagement, high inflation, rising crime rates, and electricity shortages. Only one television network, NTN24, showed coverage of the protests that took place in primarily middle-class areas, until Maduro blocked the news channel broadcast. Twitter, Facebook, and YouTube were used to fill in the gaps of information left by NTN24. The hashtag \#LaSalida was used to unify protestors and call for "the exit" of Maduro from power. The government countered with the hashtag \#VzlaUnidaContraElFascismo (Venezuela United Against Fascism), which labeled protestors as fascists and affirmed Maduro's power. Months before the protests began, Maduro was given permission to act without consultation of parliament in response to national crises. Using this power as protests gained strength in February 2014, Maduro began to block antigovernment messages on Twitter. As early as March 2014, the regime began arresting leaders of the opposition party. $45-47$ In the December 2015 legislative elections, the opposition party was expected to gain the majority of seats. The opposition was very much active on social media, using Twitter, YouTube, and Periscope to garner support. While there was no repeat of the countrywide internet blackout of 2013, there were local internet outages in 12 of the 24 states in Venezuela at some point during the campaign process. Issues with internet access on election weekend were more prevalent in states with anti-Maduro tendencies like Zulia and Tachíra. ${ }^{44}$

\section{Summary of Findings from Venezuela}

Venezuela began censoring social media just before the 2013 snap presidential election and continued throughout the 2014 nationwide protests, with selective censorship in the 2015 elections. In accordance with the Mass Political Action Hypothesis, the Venezuelan government restricted social media following mass political action in 2014 and in anticipation of election-related action in 2013 and 2014. Interestingly, the government made no move toward censoring social media calls for pro-Chavez rallies between 2011 and 2013, which suggests that the regime strategically censored messages that were antithetical to its survival while allowing pro-regime messages to circulate. Weak support for the Unlikely Action Hypothesis comes from the lack of censorship in the 2006 election, when social media use was less public and less likely to lead to lead to mass political action, especially while President Chavez rebuked any claims against him on the more accessible mainstream media. However, it may also be the case that the government was simply not well-versed in social media censorship methods at the time. Strong support for the Mainstream Media Hypothesis comes from the government curtailing mainstream media coverage prior to the largest social media censorship occurrences in 2014. This suggests that the weakening of mainstream media was a necessary precursor to curbing social media access.

\section{DISCUSSION}

Table 5 provides a summary of the results for each case. A full discussion for each hypothesis is below.

\begin{tabular}{|l|l|l|l|}
\hline Hypothesis & Iran & Turkey & Venezuela \\
\hline Mass Political Action & Strong Support & Strong Support & Strong Support \\
\hline Unlikely Action & Weak Support & Weak Support & Weak Support \\
\hline Mainstream Media & Strong Support & Strong Support & Strong Support \\
\hline
\end{tabular}

Table 5. Summary of Results for Each Country/Hypothesis

Mass Political Action Hypothesis: When social media use encourages mass political action, regimes respond with censorship.

The evidence presented in all three cases provides strong support for the first hypothesis. The governments of all three countries repress when mass protest follows a change in landscape on social media. The examples for this are censorship in Iran following protests of the 2009 election, in Turkey during the Gezi Park demonstrations in 2013, and in the Venezuelan mass protests beginning in 2014. In contrast, social media use that did not necessarily encourage mass political action was not censored. The examples for this include criticism of the Iranian government after the 2017 earthquake and dissent on the arrests of Turkish military leaders in 2011 and 2012.

Each of the nations, in at least one case, censored social media during an election campaign. Casting a ballot is very different from participating in a rally, but it is still a political action that has an impact on whether a regime remains in power. Even without the presence of mass rallies, governments repressed social media use when they anticipated that the party in opposition was gaining leverage in a campaign. This was the case in all three nations at some point, but the 2015 elections in Venezuela lend great 
support to the idea that a regime wanted to control voting outcomes, as specific states with tendencies toward anti-Maduro beliefs experienced Internet outages the most.

One qualification that should be made is that governments tend to censor social media interactions that encourage political action only when it is not in their favor. Turkey did not add to censorship of social media during the 2015 election because the social media users that expressed security concerns generally placed trust in the current government to handle threats and thus favored the regime's continuation of power. In Venezuela, social media users organized mass rallies to show support for Chavez following concerns about his health, and these were understandably favored by the government and not censored. Even though these are citizen-generated and not government-initiated activities, the government will not repress actions that are advantageous to its maintenance of power.

\section{Unlikely Action Hypothesis: When social media use encourages mass political action that is unlikely to be realized, regimes do not respond with censorship.}

Weak support for the Unlikely Action Hypothesis comes from the lack of censorship on calls for political action in early social media. The examples for this include the 2004 and 2005 elections in Iran and the 2006 election in Venezuela. In these early cases, social media use was not as widespread, and the government used its own platform of mainstream media to combat the calls for political action. Because the political action was unlikely to be realized, there was no push to censor the messages. While this provides support for the hypothesis, it is also possible that government officials were not yet skilled in censorship methods that would take some time to establish after new social media technology was developed. A lack of effective censorship methods may have alternately disabled them from repressing the messages.

Stronger support for this hypothesis comes from the lack of specific censorship of certain messages after a general mode of censorship is established. Because social media messages are less accessible except for by the few citizens with VPNs, governments may allow messages to circulate if they relieve pressure without rallying mass action. The allowed messages contain calls to action that are typically weaker, such as the 2012 difficulty in purchasing staples in Iran. In that case, the identifiable adversary was not a corrupt Iranian government, but it was the outside nations that sanctioned Iran and caused the high prices. Since outside nations could not be directly reproached, it is less likely that the already few people with access to social media would join the protests. As a result of a combination of these factors, the Iranian government allowed the messages. This proposed causal chain should be examined further in future studies, as there are not enough examples in this study to strongly affirm its validity.

Further analysis of this hypothesis might involve a smaller scale study of specific social media posts. Since this study examines larger social media movements, only posts that become viral are analyzed. Future studies may analyze posts that encourage action but do not become viral and compare them to viral posts for rates of censorship.

Mainstream Media Hypothesis: A regime in a nation with a strong independent mainstream media is less likely to repress social media than a regime in a nation with a weak mainstream media.

The Mainstream Media Hypothesis is strongly supported. Iran had a tightly state-controlled mainstream media throughout the time period of the study and also contains the earliest example of social media repression of the three nations. Iran began censoring social media in the 2008 elections, which is much earlier than Turkey and Venezuela's first instances in 2013 . In both Turkey and Venezuela, the regime took measures to restrict the mainstream media before censoring social media. In fact, the rise in prevalence of social media came as a result of Erdogan censoring mainstream broadcasts of the 2013 protests in Turkey and Maduro's blocking of NTN24's coverage of the 2014 protests in Venezuela. Further, Erdogan imprisoned journalists and shut down media outlets before arresting social media users leading up to the 2017 referendum. In all of the cases examined, limitations on the mainstream media's ability to report precede and enable social media censorship, consistent with Shadmehr and Bernhardt's theoretical research.

In each case, as the regime increased control of mainstream media and social media, the nation also generally lowered in its level of democratization. A closely related subject of this research is the process by which governments become more autocratic through their responses to social media use over time. Waldner and Lust refer to this gradual decrease in the democratic qualities of a nation as "democratic backsliding." 48 Theories describing how regimes create uneven playing fields that induce democratic backsliding include control of mainstream media, but have not yet included social media. ${ }^{49}$ Based on the findings of the third hypothesis, future theories on democratic backsliding should include thorough discussion of social media, including examining its relationship to the status of mainstream media. 


\section{CONCLUSION}

The new analysis of data from Iran, Turkey, and Venezuela confirms many of the reasons for censorship of social media generated from other cases and theoretical research. The findings also shed light on specific instances in which authoritarian regimes generally repress social media use and the types of preconditions that make a regime more likely to repress.

The major proposed reason for censorship by a regime was to reduce the likelihood of mass political action triggered by social media communication. Not only was this confirmed by all cases, it was further qualified by considering elections as opportunities for political action that may trigger temporary censorship. Selective censorship by each regime confirmed and furthered Hassid's characterization of social media use as a safety valve or pressure cooker, in which regimes only censor messages that are likely to lead to their removal from power.

The evidence provided strong support for the notion that countries with strong independent mainstream media are less likely to repress social media than countries with weak mainstream media. In fact, these cases present a bright-line scenario in which limitations on mainstream media must precede social media repression.

One major limitation of this research is that it attempts to understand a process that cannot be directly observed. Decisions about censorship are made by a combination of the thought processes of the regime leader and those acting on the leader's behalf. A more complete understanding would require that Rouhani, Erdogan, and Maduro answer questions honestly in an interview, which was well beyond the scope of the available resources. Instead, this research approximates the regime's reasoning by detailing the background information behind the censorship events and attempting to connect the dots. The resulting conclusions may not be perfect, but they are indicative of patterns common to different nations.

Future research should contextualize social media censorship in terms of general decreases in democratization. Social media censorship and control of mainstream media are likely two pieces in a much larger puzzle of the process by which democratic nations backslide. Future studies should also empirically consider factors, such as the nation's natural resource wealth and citizen's individual wealth, that were used to denote differences between cases in this paper. Previous theoretical research has found that nations with higher natural resource wealth have a higher tendency to repress social media; ${ }^{50}$ comparative study of new cases may help evaluate this hypothesis. Levels of individual wealth, indicated by GDP per capita, may also have an impact on government tendencies to repress social media.

All of these findings are significant to our understanding of when authoritarian regimes begin to repress. Social media organizations should be interested in which populations may lose access to their service based on the predictive power of the theories advanced by this research. Media freedom activists should also be interested in identifying susceptible societies and empowering citizens to maintain freedoms. The findings are pertinent to many nations in different parts of the world. Even in the nations that were studied, cases of potential social media activism and repression are ongoing-Venezuela, for example, is undergoing an economic crisis and is reportedly experiencing a resulting battle between citizens and the government over access to social media. ${ }^{51}$ The results from these case studies have strong predictive power for similar authoritarian regimes. Analysts of social media, protest, and censorship patterns benefit from the advanced understanding of what causes regimes to repress.

\section{REFERENCES}

1. Goel, V., Kumar, H., and Frenkel, S. (2018). In Sri Lanka, Facebook contends with shutdown after mob violence. The New York Times. wnw.nytimes.com/2018/03/08/technology/sri-lanka-facebook-shutdown.btml.

2. Das, S. (2017) Kashmir: govt bans Facebook, Whatsapp, Twitter and other 19 social media sites. Livemint. wnw.livemint.com/Politics/VJEGyOaZ0YHhfdxə_H5F00M/JK-govt-orders-suspension-of-Internet-services.html.

3. Specia, M., and Mozur, P. (2017) A war of words puts Facebook at the center of Myanmar's Rohingya crisis. The New York Times. wnw.nytimes.com/2017/10/27/world/asia/ myanmar-government-facebook-robingya.btml.

4. Rajagopalan, M. (2018) This country's leader shut down democracy - with a little help from Facebook. BuгzFeed. wnw. buz:afeed.com/ meghara/ facebook-cambodia-democracy?utm_term=.fnVwDr7AQK\#.ohYpMDrZxm.

5. Frenkel, S., and Benner, K. (2018) To stir discord in 2016, Russians turned most often to Facebook." The New York Times. wnw.nytimes.com/2018/02/17/technology/indictment-russian-tech-facebook.html.

6. Lohmann, S. (1994) The dynamics of informational cascades: The Monday demonstrations in Leipzig, East Germany, 198991. World Politics, 47(1), 42-101. doi:10.2307/2950679

7. Bellin, E. (2012) Reconsidering the robustness of authoritarianism in the Middle East: Lessons from the Arab spring. Comparative Politics, 44(2), 127-149. doi:10.5129/001041512798838021

8. Edmond, C. (2013) Information manipulation, coordination, and regime change. The Review of Economic Studies, 80(4 (285)), 1422-1458. doi:10.1093/restud/rdt020 
9. Shadmehr, M., and Bernhardt, D. (2015). State censorship. American Economic Journal: Microeconomics, 7(2), $280-307$. doi:10.1257/mic.20130221

10. Hassid, J. (2012). Safety valve or pressure cooker? Blogs in Chinese political life. Journal of Communication, 62(2), $212-230$. doi:10.1111/j.1460-2466.2012.01634.x

11. King, G., Pan, J., and Roberts, M. E. (2013) How censorship in China allows government criticism but silences collective expression. The American Political Science Review, 107(2), 326-343. doi:10.1017/ S0003055413000014

12. Aday, S., and United States Institute of Peace. (2012) Blogs and bullets II: New media and conflict after the Arab spring. (No. 80). Washington, DC: United States Institute of Peace.

13. Mungiu-Pippidi, A. (2013) Controlling corruption through collective action. Journal of Democracy, 24(1), $101-115$. doi:10.1353/jod.2013.0020

14. Sullivan, J. (2012) A tale of two microblogs in China. Media, Culture \& Society, 34(6), 773-783. doi:10.1177/0163443712448951

15. Polity IV Project, Political Regime Characteristics and Transitions, 1800-2017.

16. Fearon, J. (2003) Ethnic and cultural diversity by country. Journal of Economic Growth, 8(2), 195-222. Retrieved from bttp:// wmw.jstor.org/stable/40215943

17. World Bank, and OECD. (2019). World development indicators: GDP per capita (constant 2010 US\$). World Bank. https:/ / databank.worldbank.org/source/world-development-indicators

18. The World Factbook. (2018). Washington, DC: Central Intelligence Agency, 2018. https://www.cia.gov/library/publications/theworld-factbook/index.html

19. World Bank. (2019). World development indicators: Total natural resource rents. World Bank. bttps:/ / databank.worldbank.org/source/world-development-indicators

20. Country Watch Reviews. (2018) Political conditions Iran. Syndigate Media Inc. Retrieved from Lexis Nexis database at https:/ / advance-lexis-com.exproxy.tcu.edu/ api/ document?collection=newserid=urn:contentItem:5WYG-RFC1-F11P-X163-0000000 \&ontext $=1516831$

21. Murphy, B. (2004). Poll weapons: e-mail and TV: Protagonists in Iran's election duel on Internet and in media [News Report]. The Gazette (Montreal, Quebec). Retrieved from Lexis Nexis database at https:// advance-lexiscom.ezproxy.tcu.edu/api/permalink/51f0f179-c55e-4e1d-b3d1-21d68897112a/?context=1516831

22. Agence France Presse. (2005) Iranian presidential election [Newswire]. Retrieved from Lexis Nexis database at https://advancelexis-com.exproxy.tcu.edu/api/permalink/d1cda89b-6e9b-41d6-a953-611e86ba91eal ?context =1516831

23. BBC Monitoring Middle East. (2005) Iran media watch: Opinion polls on presidential election move to the Internet [News]. Retrieved from Lexis Nexis database at bttps:/ / advance-lexis-com.ezproxy.tcu.edu/api/permalink/95395b91-ffde-4be7-bcef$241 f 3 d b 564 b 8 /$ ? context $=1516831$

24. BBC Monitoring World Media. (2008) Internet messaging limited on eve of Iran elections [News]. Retrieved from Lexis Nexis database at https:// advance-lexis-com.exproxy.tcu.edu/api/permalink/e03d619d-ca84-4504-aad1Oa68f58552bf) ? context $=1516831$

25. The New York Times. (2008) Iran may block internet for election [News]. Retrieved from Lexis Nexis database at bttps:/ / advance-lexis-com.ezproxy.tcu.edu/api/permalink/261d51d0-dd6e-483e-ad64-298e23599685/?context=1516831

26. Mueller, P. S., and van Huellen, S. (2012) A revolution in 140 characters? Reflecting on the role of social networking technologies in the 2009 Iranian post-election protests: The role of social networking technologies. Policy \& Internet, 4(3-4), 184-205. doi:10.1002/poi3.16

27. Berman, I. (2015) Iranian devolution: Tehran fights the digital future. World Affairs, 178(3), 51-57.

28. Alimardani, M. (2014) The story behind Iran's censorship redirect page. Global Voices. Retrieved from Lexis Nexis database at https:/ / advance-lexis-com.exproxy.tcu.edu/api/permalink/97e610e2-ead0-4f78-ac14-8ebc5a013582/?context=1516831

29. Rahimi, B. (2015) Internet censorship in Rouhani's Iran: The "Wooden sword": Media reviews. Asian Politics \& Policy, 7(2), 336-341. doi:10.1111/aspp.12182

30. States News Service. (2012) Iranians reportedly protest against high food prices [Newswire]. Retrieved from Lexis Nexis database at https:// advance-lexis-com.ezproxy.tcu.edu/api/permalink/ 5 ef7f7b9-1574-42d6-9f75-b3bc6ef4c856/?context=1516831

31. EuroNews. (2017) Iran-Iraq earthquake: Social media images show tragic aftermath. Retrieved from Lexis Nexis database at bttps:/ / advance-lexis-com.ezproxy.tcu.edu/api/permalink/d2e6b7e4-571e-4b7e-81e8-976389297acb/?context=1516831

32. BBC Monitoring Middle East. (2017) Iran quake triggers grief, criticism among social media users [Transcript]. Retrieved from Lexis Nexis database at bttps:/ / advance-lexis-com.ezproxy.tcu.edu/ api/permalink/092e2ba9-9b72-4e55-8a49$51314 b 2 e c 32 e$ ? context $=1516831$

33. Country Watch Reviews. (2018) Political conditions Turkey. Syndigate Media Inc. Retrieved from Lexis Nexis database at bttps:/ / advance-lexis-com.ezproxy.tcu.edu/api/permalink/a5fde426-56ce-44c5-90a6-83e1 c6fe056b/?context=1516831

34. BBC Monitoring Europe. (2012) Paper says media faced discrimination at Turkish troops' funeral [News]. Retrieved from Lexis Nexis database at https:// advance-lexis-com.eaproxy.tcu.edu/api/permalink. 6 d5 d5 d06-7cc0-4207-be1a-

$83 f 719 d 7 b 366 /$ ? context $=1516831$ 
35. Vatikiotis, P., and Yörük, Z. F. (2016) Gezi movement and the networked public sphere: A comparative analysis in global context. Social Media + Society, 2(3), 205630511666218. doi:10.1177/2056305116662184

36. Arda, B (2014) The Medium of the Gezi Movement in Turkey: Viral Pictures as a Tool of Resistance. APSA 2014 Annual Meeting Paper. Available at SSRN: https://ssm.com/abstract=2453044

37. Saka, E. (2014) The AK party's social media strategy: Controlling the uncontrollable. Turkish Review, 4(4), 418.

38. Jones, D. (2017) Turkey targets social media before tight referendum. Voice of America News. Retrieved from Lexis Nexis database at https:/ / advance-lexis-com.ezproxy.tcu.edu/api/permalink/952a4d0a-7a2f-46c8-9d96-0aff76cc355b/?context=1516831

39. Kingsley, P. (2017) Turkey arrests dozens over referendum protests. The New York Times. Retrieved from Lexis Nexis database at bttps:// advance-lexis-com.ezproxy.tcu.edu/api/permalink/e5ae3433-1e5d-461a-b483-5e9672165fc6/?context=1516831

40. Country Watch Reviews. (2018) Political conditions Venezuela. Syndigate Media Inc. Retrieved from Lexis Nexis database at https:/ / advance-lexis-com.ezproxy.tcu.edu/api/permalink/c870b2a8-bace-4240-bf55-b97f4f9b8ef9/?context=1516831

41. Dominguez, C. (2013) Leveraging social media: a communications tool for heads of state in Latin America. Diplomatic Courier. https:/ / www.diplomaticourier.com/posts/leveraging-social-media-a-communications-tool-for-heads-of-state-in-latin-america-2\#.XfDHa9OtbI.link

42. Agence France Presse. (2012) Venezuela's Chavez needs more cancer surgery [Newswire]. Retrieved from Lexis Nexis database at bttps:// advance-lexis-com.ezproxy.tcu.edu/api/permalink/46649f8d-c08a-4407-ab4f-b5b611bf8f88/?context=1516831

43. Russia and CIS General Newswire. (2013) Maduro, Capriles have almost equal chances to win presidency in Venezuela [Newswire]. Retrieved from Lexis Nexis database at https:// advance-lexis-com.ezproxy.tcu.edu/api/permalink/06ffc18a-e9a0-4f04a128-c2b588f7f42b/?context $=1516831$

44. Hernández, M. (2015) Low bandwidth, high hopes: digital participation in Venezuelan elections. Global Voices. Retrieved from Lexis Nexis database at bttps:// advance-lexis-com.eaproxy.tcu.edu/api/permalink/f521cfc6-f0a5-497c-844bc4368f2114e6/? context $=1516831$

45. Ciccariello-Maher, G. (2014) LaSalida for Venezuela? New York: The Nation Company L.P. https:/ / www.thenation.com/article/ lasalida-venequelal

46. Robertson, V. (2014) Reflections amid protests and chaos in Venezuela. Global Voices. Retrieved from Lexis Nexis database at bttps:/ / advance-lexis-com.ezproxy.tcu.edu/api/permalink/ f255fdc0-059f-488b-9ea4-56cbb2cd0840/?context=1516831

47. Trinkunas, H. (2014) Toward a peaceful solution for Venezuela's crisis. States News Service. Retrieved from Lexis Nexis database at https:// advance-lexis-com.ezproxy.tcu.edu/api/permalink/ cabbfe7e-e3f1-4297-b2c9-16e425be2925/?context=1516831

48. Waldner, D., and Lust, E. (2018) Unwelcome change: Coming to terms with democratic backsliding. Annual Review of Political Science, 21(1), 93-113. doi:10.1146/ annurev-polisci-050517-114628

49. Levitsky, S., and Way, L. (2010) Democracy's past and future: Why democracy needs a level playing field. Journal of Democracy, 21(1), 57-68. doi:10.1353/jod.0.0148

50. Egorov, G., Guriev, S., and Sonin, K. (2009) Why resource-poor dictators allow freer media: A theory and evidence from panel data. American Political Science Review, 103(4), 645-668. doi:10.1017/S0003055409990219

51. Gilbert, D. (2018) Venezuela just took a huge step towards controlling all access to the internet. VICE News. bttps:// www.vice.com/en_us/article/59qww/ venezuela-maduro-tor-network-censorship

\section{ABOUT STUDENT AUTHOR}

Ezhan Hasan is a senior Political Science student at Texas Christian University, graduating in May 2020. Ezhan completed this project in Summer 2018 as part of TCU Political Science's Student Summer Research Program and has since presented at the International Studies Association- Midwest and Pi Sigma Alpha National conferences. Ezhan is currently working on his senior thesis concerning U.S. tribal law.

\section{PRESS RELEASE}

In the past 15 years, access to internet and social media has increased worldwide, making it easier to organize mass political action against the government. In response, several leaders have decided to restrict access to social media. However, very few countries restrict total access; rather, countries are selective on when, where, and how they block social media access. Combining the heavily studied case of China with knowledge of media purposes and authoritarian regime objectives, this research organizes theories of what types of factors cause regimes to censor social media. The theories are then applied to Iran, Turkey, and Venezuela over 2004 to 2017 to test and improve understandings of why regimes repress. 


\section{APPENDIX}

Table of All Country Specific Data

\begin{tabular}{|c|c|c|c|c|}
\hline Country/Year & $\begin{array}{l}\text { Ethnic } \\
\text { Fractionalization }\end{array}$ & $\begin{array}{l}\text { Natural Resource } \\
\text { Wealth }\end{array}$ & GDP per capita & Polity Score \\
\hline Iran 2004 & 0.669 & 25.03669466 & 2729.838416 & -6 \\
\hline Iran 2005 & & 32.16971023 & 3215.653433 & -6 \\
\hline Iran 2006 & & 33.84830641 & 3738.689284 & -6 \\
\hline Iran 2007 & & 28.62496832 & 4857.368371 & -6 \\
\hline Iran 2008 & & 32.76251483 & 5574.410436 & -6 \\
\hline Iran 2009 & & 18.72480243 & 5619.117621 & -6 \\
\hline Iran 2010 & & 21.70051707 & 6531.92743 & -6 \\
\hline Iran 2011 & & 26.58457236 & 7729.343353 & -6 \\
\hline Iran 2012 & & 20.02654936 & 7832.902635 & -6 \\
\hline Iran 2013 & & 24.63678444 & 6036.192088 & -7 \\
\hline Iran 2014 & & 23.84069966 & 5540.984136 & -7 \\
\hline Iran 2015 & & 13.47160625 & 4862.299729 & -7 \\
\hline Iran 2016 & & 15.95320975 & 5219.109805 & -7 \\
\hline Iran 2017 & & .. & 5415.209635 & -7 \\
\hline Turkey 2004 & 0.229 & 0.280923761 & 6040.88491 & 7 \\
\hline Turkey 2005 & & 0.283251363 & 7384.258482 & 7 \\
\hline Turkey 2006 & & 0.376265044 & 8034.606676 & 7 \\
\hline Turkey 2007 & & 0.42492435 & 9709.720022 & 7 \\
\hline Turkey 2008 & & 0.640387247 & 10850.87039 & 7 \\
\hline Turkey 2009 & & 0.383412265 & 9036.266711 & 7 \\
\hline Turkey 2010 & & 0.53836334 & 10672.40016 & 7 \\
\hline Turkey 2011 & & 0.706372609 & 11340.82362 & 9 \\
\hline Turkey 2012 & & 0.570303282 & 11720.31386 & 9 \\
\hline Turkey 2013 & & 0.48874526 & 12542.72153 & 9 \\
\hline Turkey 2014 & & 0.423737215 & 12127.46072 & 3 \\
\hline Turkey 2015 & & 0.295994769 & 10984.8052 & 3 \\
\hline Turkey 2016 & & 0.327203284 & 10862.72538 & -4 \\
\hline Turkey 2017 & & .. & 10540.618 & -4 \\
\hline Venezuela 2004 & 0.483 & 21.79830993 & 4271.372404 & 6 \\
\hline Venezuela 2005 & & 25.42053621 & 5432.688675 & 6 \\
\hline Venezuela 2006 & & 23.09964189 & 6735.797588 & 5 \\
\hline Venezuela 2007 & & 18.97014099 & 8318.803399 & 5 \\
\hline Venezuela 2008 & & 19.00754272 & 11227.23138 & 5 \\
\hline Venezuela 2009 & & 7.675022522 & 11536.14939 & -3 \\
\hline Venezuela 2010 & & 10.22749148 & 13545.26345 & -3 \\
\hline Venezuela 2011 & & 20.06330853 & 10741.57638 & -3 \\
\hline
\end{tabular}




\begin{tabular}{|l|l|l|l|l|}
\hline Venezuela 2012 & & 15.74842153 & 12755.00008 & -3 \\
\hline Venezuela 2013 & & 15.2813507 & 12237.19374 & 4 \\
\hline Venezuela 2014 & & 10.10276639 & 15692.41288 & 4 \\
\hline Venezuela 2015 &.$\cdot$ &.$\cdot$ & 4 \\
\hline Venezuela 2016 &.$\cdot$ &.. & 4 \\
\hline Venezuela 2017 &.. &.. & -3 \\
\hline
\end{tabular}

Table A1. All Country Specific Data

\section{List of Events by Country and Type}

The following is a list of major political events, derived from each nation's Country Watch report, over the period of 2004 to 2017. The list is not comprehensive, but it aims to provide a representation of major events that would incite political discussion.

The events are divided into categories of Domestic Affairs, International Affairs, and Elections. Domestic Affairs include changes in domestic policy, actions taken by the government within its own borders, and citizen-generated political action. International Affairs include any diplomatic or contentious dealings with other nations or international organizations (including terror organizations). Elections are specifically related to the occurrence of any election, a change in election rules, or a change in political parties. For Turkey's ongoing Kurdish conflict, all instances have been placed under the International Relations category for consistency. The reasoning for this is that although many Kurds live in Turkey, the ongoing conflict often involves neighboring countries, like Iraq, and members of the Kurdistan Worker's Party (PKK) engage with the Turkish government as a foreign entity would.

This lists of Domestic Affairs and Election Related events are annotated. All terror attacks are preceded by the letter T. Instances where social media use was not detected are preceded by the letter $\mathrm{N}$. Instances that will be included within an ongoing event elsewhere are preceded by the letter E. Instances that were directly included in the case study analysis are preceded by the letter I. Since International Relations events are systematically excluded, the lists of International Relations events are generally not annotated, except for if the event was included elsewhere or it is a terror attack.

Iran-Domestic Affairs

- (N) May 2006: Members of the Azeri ethnic minority group protest a newspaper cartoon that compares them to an insect.

- (T) February 2007: Sunni Muslim group claims responsibility for attack on Iran's Revolutionary Guard, leading to 11 deaths and several subsequent clashes between militants and armed forces.

- (T) May 2009: A mosque in Zahedan, a province of primarily Sunni Muslims, was bombed, leaving around 80 casualties.

- (T) July 2010: Suicide Bomb attacks leave around 130 casualties at mosque in Zahedan.

- (E) September 2010: The pro-government Basij militia attacked the home of opposition leader Mehdi Karroubi. (part of ongoing 2009 protests)

- (T) December 2010: A suicide bombing targets the Ashura celebrations in Chabahar.

- (E) February 2011: Opposition leaders Mir Hossein Mousavi and Mehdi Karroubi are arrested after calling on Iranians to protest in the streets. (part of ongoing 2009 protests)

- (E) February 2011: Thousands of protestors march against the government in Tehran, Ishfahan, Mashhad, and Shiraz. The government deploys security forces in response. In the protest, the daughter of former president Rafsanjani was arrested. (part of ongoing 2009 protests)

- (E) Mid-2011: Well-known activist Mehdi Karroubi was reported missing, as his family and close friends had not seen him for as many as six weeks. (part of ongoing 2009 protests)

- (I) 2012: Iran reportedly has difficulty purchasing staples, such as rice and cooking oil, due to economic sanctions.

- (I) November 2017: Iran experiences earthquake.

\section{Iran-Election Related}

- (I) February - June 2004: The Council of Guardians disqualified thousands of reformist candidates from parliamentary elections. Leading intellectuals and journalists called for a boycott of the election to protest but could not penetrate mainstream media, so they used e-mails and mobile phone messages instead. Conservatives gained control of the largest portions of public office.

- (I) June 2005: Despite calls to boycott the presidential election due to disqualification of reformist and female candidates, large numbers of Iranians show at the polls to elect the conservative Mahmoud Ahmadinejad. 
- $\quad(N)$ December 2006: Along with several moderates gaining public office, former president and moderate Akbar Hashemi Rafsanjani was elected to the Assembly of Experts.

- (I) March 2008: Conservatives maintain control of parliament after elections in March 2008.

- (I) 2009: The primary candidates in the 2009 presidential election were former Prime Minister Mir Hossein Mousavi and incumbent Mahmoud Ahmadinejad. Election turnout in June 2009 was so high that polling stations had to extend operations for several hours due to long lines of voters. After polls closed, both Ahmadinejad and Mousavi claimed victory, with no official word on the matter. Soon after, Mousavi's website was shut off, his mobile messaging cut off, social networking curtailed, and headquarters reportedly raided. Iranian state media then declared Ahmadinejad the winner. What followed was the largest series of protests in Iran since 1979, which were called the "Green Revolution" by supporters of the reformists Mousavi and Mehdi Karroubi.

- (E) February 2012: Parliamentary elections (part of ongoing response to 2009)

- (E) May 2013: Presidential elections. Hassan Rouhani is elected, and many in Iran rejoice the exit of Ahmadinejad. (part of ongoing response to 2009)

- (E) February 2016: In the parliamentary elections, several candidates are initially disqualified, but following protests, they are reinstated. (part of ongoing response to 2009)

- (N) May 2017: Presidential elections. Rouhani is re-elected.

\section{Iran-International Relations}

- February 2007: The UN deadline for Iran to suspend all nuclear activities passes, as Iran is in noncompliance.

- March 2007: 15 members of the British Navy were captured by Iranian forces.

- January 2008: The U.S. claims that 5 of its Navy ships were threatened in the Strait of Hormuz by Iranian ships.

- July 2008: U.S. begins first diplomatic talks with Iran since 1979.

- October 2009: Tensions increase with Pakistan, as Pakistan detains members of Iran's Revolutionary Guard.

- November 2011: Demonstrations against embassies of Western nations ensue, as the UK degrades its ties with Iran.

- February 2012: Israeli leadership threatens military action in response to Iran nuclear situation.

- July 2012: Israeli leadership blames Iran and Hezbollah for an attack in a Bulgarian airport.

- April-July 2015: Iran backs the rebel Houthis in Yemeni conflict.

- May-July 2015: The final round of talks on the Iran Nuclear Issue with the United States lead to the finalization of a Joint Comprehensive Plan of Action.

- October 2015: The President of Yemen cuts all diplomatic ties with Iran.

- January 2016: Saudi Arabia executes an Iranian cleric

- January 2016: 10 U.S. sailors detained by Iranian forces.

- October 2017: U.S. president decertifies the Iran nuclear deal reached in 2015.

\section{Venezuela-Domestic Affairs}

- (N) March 2006: President Hugo Chavez announces a new flag that will be gradually incorporated over the next 5 years.

- (N) January 2007: The National Assembly approves legislation that grants Chavez a bypass of parliament for executive action.

- (N) May 2007: Chavez shuts down the oldest public television station in the country. (no social media activity detected)

- (N) December 2010: An "Enabling law" is passed, granting Chavez more executive power in the face of crisis.

- (I) June 2011-March 2013: Chavez battles cancer and is taken to a hospital in Cuba. The Venezuelan leader makes several visits to and from his country during this time and continues to hold that he is not sick. Chavez is also re-elected during this time. He dies in March 2013 and is succeeded by interim replacement Nicolas Maduro.

- (E) November 2013: Maduro is given permission to act without consultation of parliament in response to national crises. (will be included in forthcoming Maduro protest)

- (I) 2014: Protests ensue over economic mismanagement, high inflation, rising crime rates, and electricity shortage. In February, social media access is blocked by Maduro. In March, mayors of the opposing party are arrested and put on trial. Protest leaders Leopoldo Lopez and Maria Corina are arrested in July and December, respectively.

- (E) February 2015: As protests of Maduro continue, teenager Kluiver Roa Nunez is killed by a police officer. Maduro condemns the death of Nunez. (included in ongoing 2014 protests)

- (E) Late 2016: Protests of the Maduro regime continue. (included as ongoing 2014 protests) 
Venezuela-Election Related

- (N) February-August 2004: A petition to remove President Hugo Chavez from office by referendum vote comes to fruition. In the referendum vote, Chavez is able to maintain his position.

- (N) August 2005: Venezuelans march for electoral reform.

- (N) December 2005: Legislative elections. Voter turnout is lower than usual.

- (I) August - December 2006: Presidential election season leads to re-election of Chavez.

- (N) November - December 2007: The National Assembly moves to consolidate presidential power, including ending term limits. The move is pending approval by referendum vote in December, at which time it does not pass.

- (N) November 2008: Municipal elections. Chavez claims victory when several of his own party assume offices.

- (N) February 2009: Another referendum on ending term limits results in passing of the new policy.

- (N) September 2010: Legislative elections

- (E) October 2012: Presidential elections. Several rallies begin in September 2012. Chavez is re-elected, despite health concerns. (included in Chavez health concerns)

- (I) April 2013: Snap presidential elections. Interim president Nicolas Maduro is elected.

- (I) December 2015: Legislative elections. The opposition party gains the most seats.

- (E) July 2017: Maduro announces a referendum to dissolve parliament and give himself full control over the nation. An unofficial referendum is announced by the opposition party to rebuke Maduro's referendum. At the end of the month, Maduro's referendum gives him ultimate power to dismiss anyone from any office in the country. (included in ongoing protests since 2014)

Venezuela_International Relations

- Early 2005: Colombia allegedly encroaches onto Venezuelan territory, leading to protest.

- April - November 2005: A series of events lead to worse relations with the United States. In April, the U.S. secretary of state called Venezuela a negative influence in South America and began to monitor arms sales to the country. In May, Venezuelans demonstrated against the U.S. not returning alleged terrorist Luis Posa Carriles to Venezuelan custody. In July, Venezuela began to investigate the U.S. Drug Enforcement Agency's involvement in the country as an alleged spy operation. In August, U.S. citizen Pat Robertson called for Chavez's assassination, and Venezuela charged him with a terror threat, but the U.S. did not turn him over. In September, Chavez spoke against the U.S. at the UN assembly. In November, Chavez led an anti-U.S. rally in Argentina.

- April 2006: U.S. ambassador is pelted with fruit in Caracas.

- July 2006: Venezuela applies to join South American Mercosur trade bloc

- September 2006: Chavez once again bashes the U.S. in front of the UN.

- November 2006: A bid for Venezuela to gain a non-permanent seat on the UN Security Counsel ends in failure.

- November 2007: Chavez freezes bilateral ties with Colombia and stops negotiating the release of hostages by FARC, leading to protests outside his home.

- January - June 2008: Chavez begins talks with Colombia again, with aims to have hostages released to their families

- September - December 2008: A series of increased ties with Russia. In September, Chavez meets with Russian president. In December, the two nations begin joint military exercises and Russia sells weaponry to Venezuela.

- November 2009: Due to conflict with Colombia, Mercosur members revisit decision to allow Venezuelan entry.

- July 2012: Venezuela is granted entry into Mercosur after Paraguay is removed from trade bloc.

- March 2015: U.S. places sanctions on six officials in Venezuela.

- August 2017: U.S. president says he would not rule out military option in Venezuela

Turkey_Domestic Affairs

- (N) January 2004: Turkey bans the death penalty

- (T) March, July 2004: Terrorist attacks in Istanbul

- (N) 2005-2006: several writers and journalists jailed, including Hrat Dink and Orhan Pamuk.

- (N) May 2006: Judge Mustafa Ozbilgin shot and killed by someone alleged to be protesting his secular ruling on headscarves.

- (N) January 2007: Hrat Dink assassinated. The trial was set for July 2007.

- (T) June - July 2008: A series of terror attacks, including an attack on the U.S. consulate in June and another in Istanbul in July. 
- (N) July 2008: The Justice and Development Party was put on trial for its religious leanings. It was at risk of being completely disbanded for violating the Turkish tradition of secularism. Because of a technicality, it is allowed to continue to exist.

- (N) December 2009: The Turkish Constitutional Court bans the Kurdish nationalist Democratic Society Party.

- (N) December 2009 - February 2010: A series of arrests of top military officials allegedly conspiring against Turkish leadership.

- (T) October 2010: Suicide bombing in Istanbul.

- (I) August 2011 - April 2012: Several more generals were arrested in anti-government conspiracies, including one prominent General Basbug.

- (I) June - July 2013: Demonstrations surged in Gezi Park after government plans to repurpose the park. The mass rallies were fueled by social media, and Prime Minister Tayyip Erdogan sent several warnings for protests to cease. In July, a court ruled against the changes to the park, but protests and clashes with police continued afterward.

- (I) December 2013 - March 2014: Tapes were released in December 2013 of Prime Minister Erdogan talking to his son, alluding to corrupt dealings. Protests ensued in the beginning of 2014 . 350 police officers were dismissed or reassigned positions by Erdogan. In order to stop the spreading information on the issue, Erdogan shut down Twitter in March 2014. Erdogan would be running for president later in 2014.

- (I) March 2014: In 2013, General Basbug was sentenced to life in prison, but he was released on a technicality in March 2014.

- (E) September - October 2015: President Erdogan tightens his grip on the media, as more journalists are arrested. (included in series of earlier censorships)

- (I) July 2016: A military coup was attempted, and subsequently several media outlets were shut down.

Turkey_Election Related

- (N) May - July 2007: Parliament was set to elect a president in May but could not come to an agreement. The country's officials agreed to move parliamentary elections that were originally scheduled for November to July. The July elections for parliament were won by the Justice and Development Party (AKP), and they appointed Abdullah Gul as president.

- (N) September 2010: In a referendum vote, voters approved constitutional amendments that gave the ruling party more power over state institutions.

- (N) June 2011: Parliamentary elections.

- (I) August 2014: Turkey had its first direct presidential elections and Prime Minister Tayyip Erdogan of the AKP party was elected.

- (I) June 2015 - November 2015: Parliamentary elections were held in June, and the AKP party won a plurality of seats but not a majority. Parliament found itself at an impasse in electing a prime minister until August, when they decided to hold another snap election in November. That election resulted in AKP earning a majority of seats, and Ahmet Davutoglu was elected prime minister.

- (I) April 2017: A referendum was held to increase the executive power of the president. With a 51.5 percent vote, the motion passed.

Turkey-International Relations

- October - December 2004: Turkey's attempt to become a member-state of the EU is unsuccessful, as Cyprus is added instead.

- May 2006: Turkish and Greek planes collide.

- June 2006: A meeting in Luxemburg to discuss whether Turkey will join as a member-state.

- October 2006: The Kurdistan Worker's Party (PKK) calls for a ceasefire after ongoing conflict. Their request is rejected by the Turkish government.

- November 2006: Pope Benedict XVI visits Turkey.

- (T) Early 2007: a series of attacks ensue allegedly by members of the PKK.

- (T) September - December 2007: More attacks by members of PKK, including in Sirnak and on the border with Iraq in September and October, respectively. The Turkish government calls for the rebels to be overturned by the Iraqi government and threatens airstrikes if the request is not met. Turkey engages in airstrikes against Iraq in December.

- October 2009: Turkey and Armenia re-establish ties after longtime cold relations.

- September 2011: Turkish government challenges Israel’s blockade of Gaza. 
- June-December 2012: A series of conflicts with Syria occurs. A Turkish jet is shot down by Syrian forces in June. Turkish security officials force a Syrian jet to land in October. Syrian mortar fire kills five on the Turkish-Syrian border in October. Turkey authorizes military action on Syria in October and is backed by the U.S. in this endeavor in December.

- (E) July - September 2015: A series of terror attacks occur, in which both the PKK and ISIS are separately allegedly responsible. In some cases, a group claims responsibility, but in others, like an October attack on a peace rally in Ankara, it is unknown who is responsible. The Turkish response is primarily focused on the PKK (included as part of discussion of 2015 elections)

- October - December 2015: Russia violates Turkish airspace on separate occasions during these three months, leading to tense relations between the two nations.

- (T) January - June 2016: Another series of terror attacks occurs. President Tayyip Erdogan blames the Kurds, although it is unclear who is responsible in some cases.

- (T) August 2016: ISIS is found to be responsible for an attack on a wedding.

- December 2016: The Russian Ambassador to Turkey is assassinated.

- (T) January 2017: An investigation into a nightclub attack finds a Central Asian terror organization to be responsible. 